\title{
Memurnikan Mahkamah Konstitusi
}

\author{
Muhammad Iwan Satriawan ${ }^{1}$ \\ Mukhlis Mukhlis ${ }^{2}$ \\ ${ }^{I}$ Fakultas Hukum Universitas Negeri Lampung, Lampung, Indonesia \\ E-mail: i_santri@yahoo.co.id \\ ${ }^{2}$ Fakultas Hukum Universitas Trunojoyo Madura, Bangkalan, Indonesia
}

\begin{abstract}
This study will focus discuss to changes in the authority of the constitutional court in indonesia. That since given authority decide a dispute the outcome of an election both at the central and local the constitutional court as if stuck to the award political reasons and there are several judge involved a corruption scandal decisions dispute the outcome of an election. So the establishment of judicial special election into a the substance of things not cleared by the formation of function constitutional court (M.K) as a squire the constitution where whose main duty is interpret the act. This research uses the method juridical normative by comparing function $m . k$ in some countries and how the application of ideal in Indonesia.
\end{abstract}

Keywords: Constitutional Court, Judicial special election.

\section{A. PENDAHULUAN.}

Dalam sejarah ketatanegaraan Indonesia, gagasan untuk penyerahan kewenangan menguji produk kekuasaan legislatif terhadap UUD kepada kekuasaan kehakiman telah lama dikemukakan oleh para pendiri dan tokoh bangsa, bisa terbilang sejak awal mereka merancang republik. Hanya saja perjuangan tersebut hingga runtuhnya kekuasaan orde baru pada 1998 selalu kandas di tengah jalan ${ }^{1}$.

\footnotetext{
${ }^{1}$ Benny K. Harman, Mempertimbangkan Mahkamah Konstitusi, (Jakarta: Gramedia, 2013), h, 1
}

Prinsip dan pelaksanaan pengujian peraturan perundang-undangan berkaitan erat dengan prinsip kekuasaan negara, baik pembagian kekuasaan negara (distribution of power) maupun pemisahan kekuasaan negara (separation of power $)^{2}$. Yang menurut teori dasarnya terdiri dari legislatif, eksekutif dan yudikatif.

Munculnya Mahkamah Konstitusi di Indonesia selain diawali dari ketidak percayaan masyarakat terhadap keberadaan lembaga-lembaga negara yang sudah ada khususnya dalam lingkup

2 Zainal Arifin Hoesein, Judicial Review di Mahkamah Agung RI, (Jakarta: Rajawali Press, 2009), h, 71 
peradilan selama era orde baru juga karena adanya kebutuhan dasar (based need) akan adanya lembaga khusus yang mampu menguji produk-produk legislatif. Maka amandemen UUD 1945 mengamanatkan salah satunya adanya lembaga khusus pengujian undang undang terhadap Undang-Undang Dasar ${ }^{3}$. Tujuannya adalah untuk mengkontrol undang-undang agar sesuai dengan UUD, baik secara formil maupun materiilnya.

Menurut Maurice Duverger, juducial control adalah penting agar undang-undang atau peraturan perundang-undangan tidak menyimpang dari Undang-Undang Dasar atau konstitusi. Undang-Undang Dasar akan kehilangan asas-asasnya dan akan menjadi rangkaian kata-kata yang tidak ada artinya sama sekali kalau tidak ada lembaga-lembaga yang mempertahankan dan menjaga kehormatan hukum tersebut ${ }^{4}$.

Senada dengan hal tersebut, Cappeletti membedakan dua sistem pengawasan yang lazim dilakukan, yaitu pengawasan secara yudisial (judicial review) dan pengawasan secara politik (political review). Pengawasan secara yudisial artinya pengawasan yang dilakukan oleh badan atau badan-badan yudisial. Sedangkan pengawasan secara politik artinya pengawasan yang dilakukan oleh badan-badan non-yudisial (lazimnya adalah badan politik). Baik pengawasan secara politik atau pun pengawasan secara yudisial yang dilakukan dengan cara menilai atau menguji (review), apakah suatu undang-undang atau peraturan perundang-undangan lainnya atau tindakan-tindakan pemerintah yang ada (existing) atau akan diundangkan (akan dilaksanakan) bertentangan atau tidak dengan ketentuan - ketentuan Undang-Undang Dasar atau ketentuan -

3 Pasal 24 ayat (2) UUD 1945

4 Maurice Duverger dalam Mukhlis Taib, Dinamika Perundang-Undangan di Indonesia, (Jakarta:Reflika Aditama,2017), h, 266 ketentuan lain yang lebih tinggi daripada peraturan perundang - undangan atau tindakan pemerintah yang sedang dinilai. Wewenang menilai tersebut dalam kepustakaan disebut sebagai hak menguji (toetsingrecht $)^{5}$.

Disamping istilah hak uji materiil sebagai bagian dari konsep pengujian peraturan perundang-undangan secara yudisial, di Indonesia juga dikenal istilah judicial review. Baik hak uji materiil maupun judicial review ini sama-sama bertumpu pada asas "lex superior derogat lex inferiori" (peraturan yang lebih tinggi mengesampingkan peraturan yang lebih rendah) ${ }^{6}$.

Namun dalam praktik muncul kerancuan pemaknaan antara judicial review dan toetsingrecht. Hak menguji (toetsingrecht) merupakan kewenangan untuk menilai peraturan perundang undangan terhadap UUD, sedangkan judicial review tidak hanya menilai peraturan perundang - undangan saja melainkan juga administrative action terhadap UUD. Berikutnya adalah hak menguji (toetsingrecht) terhadap peraturan perundang - undangan tidak hanya dimiliki oleh hakim, akan tetapi juga oleh lembaga lain yang diberi kewenangan tersebut berdasarkan peraturan perundang - undangan, sedangkan judicial review hanya merupakan kewenangan dari hakim pengadilan dalam kasus konkret di pengadilan ${ }^{7}$.

Menurut Vicki C.Jackson dan Mark Tushnet pada dasarnya terdapat dua

5 Mauro Cappelleti dalam Ni'matul Hudan dan R. Nazriyah, Teori dan Pengujian Peraturan Perundang-Undangan, (Bandung: Nusa Media, 2011), h, 125

6 Widodo Ekatjahjana, Pengujian Peraturan Perundang-Undangan Menurut UUD 1945, Sebuah disertasi Progam Pasca Sarjana UNPAD, Tahun 2007 tidak diterbitkan, h, 42

${ }^{7}$ Fatmawati dalam King Faisal Sulaiman, Teori Peraturan Perundang-Undangan dan Aspek Pengujiannya, (Yogyakarta: Thafamedia, 2017), $\mathrm{h}, 105-106$ 
bentuk atau model lembaga yang melaksanakan constitutional judicial review, yaitu the decentralized model dan the centralized model ${ }^{8}$. Pada model decentralized model kekuasaan untuk melakukan judicial review tidak dilakukan oleh satu lembaga peradilan saja atau terpusat, melainkan dapat dilakukan oleh banyak lembaga peradilan seperti peradilan federal maupun peradilan negara bagian sebagaimana dipraktikkan oleh Amerika Serikat. Berikutnya adalah the centralized model yang hanya terdapat satu lembaga khusus dalam melakukan judicial review. Pada model ini banyak dipraktikkan di negara-negara Eropa.

Indonesia sendiri menganut paham centralized model dimana menjadikan Mahkamah Konstitusi sebagai lembaga yang berwenang untuk menguji undang-undang terhadap UUD $^{9}$ dan Mahkamah Agung untuk menguji peraturan perundang-undangan dibawah undang-undang terhadap undang-undang.

Terjadinya dualisme judicial review 10 di Indonesia dengan memisahkan hak uji peraturan perundang-undangan antara Mahkamah Konstitusi yang hanya memiliki kewenangan melakukan uji undang-undang Terhadap Undang-Undang Dasar 1945 dan Mahkamah Agung yang memiliki kewenangan uji peraturan perundang-undangan di bawah undang-undang terhadap undang-undang, telah menghadirkan kekaburan konsep

${ }^{8}$ Vicky C.Jackson dan Mak Tushnet dalam Feri Amsari,Perubahan UUD 1945,Edisi Revisi (Jakarta: Rajawali Press, 2013), h, 144

9 Pasal 24C ayat (1) UUD 1945

10 Hal berbeda dikemukakan oleh Jazim Hamidi bahwa beliau lebih suka menggunakan trem atau istilah pembagian judicial review. Hal ini terkait kewenangan M.K yang menguji undang-undang terhadap UUD 1945 dan kewenangan MA yang menguji peraturan perundang-undangan dibawah undang-undang terhadap undang-undang. Hasil wawancara pada tanggal 6 Oktober 2017 di Fakultas Hukum Universitas Brawijaya pukul 13.00 WIB kekuasaan kehakiman yang dianut Indonesia. Sebagai negara yang kental dengan corak civil law seharusnya kewenangan hak uji peraturan perundang-undangan murni menjadi milik Mahkamah Konstitusi, sedangkan kewenangan mengawal keadilan masyarakat diintegrasikan dalam kewenangan Mahkamah Agung ${ }^{11}$.

Hal ini ditambah lagi dengan tugas tambahan Mahkamah Konstitusi tidak hanya melakukan pengujian undang-undang terhadap UUD 1945, melainkan ada 3(tiga) dan 1 (satu) kewajiban ${ }^{12}$ lain yang juga dibebankan kepada Mahkamah Konstitusi. Yang dalam perkembangannya beban Mahkamah Konstitusi semakin diperberat dengan dimasukkannya juga sengketa pemilihan kepala daerah (pemilukada) sebagai wewenang Mahkamah Konstusi via Undang-Undang No.12 Tahun 2008 tentang Perubahan Undang-Undang No.32 Tahun 2004 tentang Pemerintahan Daerah $^{13}$.

Masukknya M.K dalam memutus sengketa pemilu menjadikan M.K masuk dalam peradilan politik karena pemilu sangat dekat sekali hubungannya dengan politik. Fenomena Peradilan Politik (judicialization of politics) tersebut dapat dikatakan merupakan sesuatu yang lazim dalam suatu negara demokrasi konstitutional, akan tetapi tidak sedikit pula yang bersifat sekeptis terhadap fenomena tersebut dan mengkritiknya dikarenakan dengan masuknya perkara-perkara politik tersebut maka pengadilan akan menggunakan pertimbangan politik dalam pengambilan keputusannya, atas dasar itulah Jonghyun Park dalam tulisannya menyatakan bahwa fenomena judicialization of politics dapat

11 Sudirman, Memurnikan Kewenangan Mahkamah Konstitusi Sebagai Lembaga Pengawal Konstitusi, Jurnal Ilmiah Pendidikan Pancasila dan Kewarganegaraan, Tahun 1 Nomor 1 Juni 2016, h, 52

12 Pasal 24C ayat (2) UUD 1945

${ }^{13}$ Pasal 236C UU No.12 Tahun 2008 
menghancurkan nilai-nilai negara hukum (rule of law) ${ }^{14}$.

Faktanya pemberian beban tambahan ini berdampak sangat nyata pada banyak terkurasnya energi para hakim Mahkamah Konstitusi, sehingga pelaksanaan kewenangan pengujian undang-undang terhadap UUD 1945 seolah-olah seperti "dikalahkan" oleh pelaksanaan wewenang penyelesaian sengketa pemilu baik pemilu presiden, legislatif dan kepala daerah.

Berdasarkan data yang ada sejak pengalihan kewenangan memutus sengketa pemilukada sejak tahun 2008 sampai pertengahan Agustus 2013, Mahkamah Konstitusi telah memutus 598 permohonan. Sedangkan semenjak dilakukan pemilukada serentak pada tahun 2015, Mahkamah Konstitusi telah menerima sebanyak 88 gugatan sengketa dan pada tahun 2017 Mahkamah Konstitusi menerima sebanyak 49 gugatan sengketa sehingga total semenjak diberlakukannya pemilukada serentak, Mahkamah Konstitusi telah menerima 137 gugatan sengketa pemilukada. Sedangkan untuk pengujian undang-undang, pada tahun 2016 Mahkamah Konstitusi telah menerima 111 permohonan pengujian undang-undang ditambah dengan sisa perkara pada tahun 2015 sebanyak 63 perkara sehingga total ada 174 judicial review sepanjang tahun 2016. Dampak lainnya dan tidak kalah pentingnya adalah terseretnya beberapa hakim Mahkamah Konstitusi kepada kasus pelanggaran kode etik ${ }^{15}$ dan kasus suap ${ }^{16}$

14 Abdurrahman Satrio, Kewenangan Mahkamah Konstitusi Memutus Perselisihan Hasil Pemilu Sebagai Bentuk Judicialization of Politics, Jurnal Konstitusi, Volume 12 Nomor 1 Maret 2015, h,125, Mahkamah konstitusi:Jakarta

15 Kasus Arsyad Sanusi dianggap melanggar kode etik karena ada anggota keluarganya yang berhubungan dengan pihak yang sedang berpekara dimana salah satu hakimnya adalah Arsyad Sanusi. Baca dalam http://www.hukumonline.com/berita/baca/lt4d54d da21b2c0/hakim-arsyad-terbukti-langgar-kode-eti yang melibatkan peserta atau kontestan pemilukada.

Realitas ini menunjukkan bahwa sudah saatnya untuk mengembalikan kemurnian keberadaan Mahkamah Konstitusi sebagai lembaga pengujian undang-undang, pemutus sengketa antar lembaga negara, pembubaran partai politik dan kewajiban memberikan putusan atas pendapat DPR mengenai impeachment terhadap Presiden dan atau Wakil Presiden. Dan bagaimana segera membentuk peradilan khusus sengketa pemilu yang akan diselesaikan oleh lembaga peradilan khusus pemilu

\section{B. PEMBAHASAN}

\section{Memurnikan Mahkamah Konstitusi}

Titik tolak pelaksanaan demokrasi adalah pada premis bahwa partisipasi rakyat yang sebesar-besarnya diperlukan dalam menjalankan penyelenggaraan negara, sebab dalam prinsip yang menjadi dasar bagi penyelenggaraan negara kekuasaan disanggah oleh prinsip demokrasi yaitu dari, oleh dan untuk rakyat. Disini penekanan dalam kekuasaan atau kedaulatan suatu negara sesungguhnya berasal dari rakyat, begitu juga dalam pelaksanaannya. Pada hakikatnya, rakyatlah yang akan menjalankan kedaulatan itu untuk mencapai kesejahteraan ${ }^{17}$. Yang kemudian kedaulatan rakyat tersebut di Indonesia dilaksanakan menurut Undang-Undang Dasar 18 sebagai implementasi dari keberadaan negara

k, diakses pada 9 Oktober 2017 pukul 16.45 WIB

16 Kasus Akil Mochtar dengan putusan MA Nomor 336 K/Pid.Sus/2015 sedangkan kasus Patrilialis Akbar baca di http://nasional.kompas.com/read/2017/09/12/1012 4921/patrialis-akbar-tidak-ajukan-banding-atas-vo nis-8-tahun-penjara

17 Veri Junaidi,Mahkamah Konstitusi Bukan Mahkamah Kalkulator,(Jakarta:Themis Book,2013),hlm.25

18 Pasal 1 ayat (2) UUD 1945 
hukum ${ }^{19}$ (rechtstaat) bukan negara kekuasaan (machtstaat)

Sebagai negara hukum, maka untuk melaksanakan dan menegakkan hukum diperlukan lembaga peradilan yang berwenang di bidangnya. Yang dalam perkembangannya di Indonesia lembaga peradilan tersebut pada puncaknya terbagi menjadi dua yaitu Mahkamah Agung dan Mahkamah Konstitusi.

Mahkamah Agung sendiri menjadi puncak dari 4 (empat) lingkungan peradilan di Indonesia yaitu peradilan umum, peradilan militer, peradilan agama dan peradilan Tata Usaha Negara.

Sedangkan Mahkamah Konstitusi adalah lembaga tinggi negara baru yang lahir akibat amandemen UUD 1945. Mahkamah Konstitusi sendiri tidak mempunyai lembaga peradilan dibawahnya karena merupakan badan peradilan pada tingkat pertama dan terakhir.

Secara filosofis ide dasar pembentukan Mahkamah Konstitusi adalah untuk menciptakan sebuah sistem ketatanegaraan di Indonesia yang menganut asas pemisahan kekuasaan (separation of power) secara fungsional dan menerapkan check and balances ${ }^{20}$. Selain itu menurut Jimly, keberadaan Mahkamah Konstiusi sekaligus untuk menjaga pemerintahan negara yang stabil dan juga merupakan koreksi terhadap pengalaman kehidupan ketatanegaraan dimasa lalu yang ditimbulkan oleh tafsir ganda terhadap konstitusi. ${ }^{21}$.

Dalam perjalanannya pelbagai putusan-putusan fenomenal khususnya mengenai pengujian undang-undang terhadap UUD 1945 telah mewarnai periode awal berdirinya Mahkamah

19 Pasal 1 ayat (3) UUD 1945

20 Thorkis Pane, Kemungkinan Peraturan Perundang-Undangan di Bawah Undang-Undang sebagai Objek Pengujian Mahkamah Konstitusi, dalam Jurnal Hukum dan Pembangunan ,Tahun ke-41 No.3 Juli 2011,hlm.398

21 Jimly Asshidiqie, Model-Model Pengujian Konstitusional di Berbagai Negara, (Jakarta:KONpress,2005),hlm.19-20
Konstitusi pada tahun 2003 hingga sekarang seolah telah menerbitkan harapan baru warga masyarakat akan hadirnya lembaga peradilan yang ideal sesuai dengan impiannya. Beberapa putusan Mahkamah Konstitusi yang fenomenal adalah sebagai berikut: (1)No.011-017/PUU-I/2003 tentang pemulihan hak politik eks anggota PKI;(2)No.021-022/PUU-I/2003 tentang pembatalan UU ketenaga listrikan;(3) No.46/PUU-VIII/2010 tentang hubungan anak luar nikah dengan bapaknya;(4)No.5/PUU-V/2007 tentang calon perseorangan dalam Pemilukada (5)No.56/PUU-XIV/2016 tentang pembatalan perda oleh Gubernur dan Menteri.

Memurnikan berarti menurut Kamus Besar Bahasa Indonesia adalah membersihkan, meluruskan, menjernihkan ${ }^{22}$. Jika mengacu kepada kewenangan M.K dan semangat pendirian M.K diawal adalah untuk menguji produk undang-undang terhadap UUD, maka dinamakan mahkamah konstitusi yang tugas utamanya adalah menjaga kehormatan dan kewibawaan UUD.

Memurnikan MK sesungguhnya dalam pendapat penulis didasarkan pada konteks normatif yaitu bahwa dengan adanya penambahan atau perluasan kewenangan MK terkait penyelesaian Sengketa Hasil Pemilu dan Pemilukada tentu akan memiliki konsekuensi logis baik secara hukum lebih-lebih secara politik. Dengan sendirinya apabila perluasan kewenangan ini tetap menjadi bagian dari MK, maka kedepan MK akan terjebak pada kepentingan politik kekuasaan terlepas hal itu bagi sebagian pihak dimaknai sebagai suatu langkah maju dalam peradaban demokrasi di Indonesia, dan bagi pihak lain hal tersebut dipandang sebagai alat atau instrumen politik kekuasaan.

22 Kbbi.kata.web.id/memurnikan/ diakses pada tgl 8 Oktober 2017 pukul 06.54 
Konteks memurnikan MK dari jebakan politik kekuasaan dari penyelesaian sengketa hasil pemilu dan pemilukada ini pada hakikatnya selaras dan sejalan dengan Teori Hukum Murni yang dicetuskan oleh Hans Kelsen, dimana teori ini muncul atas kritik terhadap teori hukum sebelumnya yaitu Analytical Jurisprudence. Teori Hukum Murni memandang hukum sebagai norma pada tataran the Ought atau das Sollen, yang terpisah dari bidang empiris, karena Austin mengajarkan bahwa hukum adalah perintah yang berada pada tataran the Is atau das Seitz di bidang empiris. Dengan demikian, Teori Hukum Murni membebaskan hukum dari anasir-anasir non-hukum, seperti misalnya psikologi, sosiologi, etika (filsafat moral) dan politik. Pemurnian hukum dari anasir-anasir non-hukum tersebut dilakukan dengan menggunakan filsafat neo-kantian mazhab Marburg sebagai daftar pemikirannya. Neo-kantianisme mazhab Marburg memisahkan secara tajam antara the Ought atau das Sollen dengan the Is I das Sin, dan, antara bentuk (Form) dengan materi (matter). ${ }^{23}$

Untuk itu, dalam rangka mengembalikan marwah dan martabat lembaga MK (tentu saja juga para Hakim-nya), penulis berpendapat bahwa konteks memurnikan MK adalah semata-mata untuk menjaga kredibilitas secara konstitusional agar tidak "terjebak" pada kepentingan-kepentingan politik kekuasaan yang justru pada saat ini telah memberikan bukti nyata bahwa dengan perluasan kewenangan dalam menyelesaikan Sengketa Hasil Pemilu dan Pemilukada, MK telah terjerembab dalam kubangan politik kekuasaan (baca: kasus Arsyad Sanusi dan Akil Mochtar). Tentu apa yang dialami MK saat ini telah mengalami pergeseran fungsi yang luar biasa, tidak saja dalam hal menjaga

23 Lihat dalam: http://orintononline.blogspot.co.id/2013/02/teori-h ukum-murni.html, diakses pada Hari Senin, 09 Oktober 2017. konstitusi tetapi juga dalam hal menjaga moral konstitusional para Hakim dari pengaruh politik kekuasaan. Lembaga MK harus keluar dari anasir-anasir kepentingan politik kekuasaan dengan cara mengembalikan perluasan kewenangan itu pada lembaga lain di luar MK, karena sesungguhnya MK tanpa memiliki kewenangan itu sudah merupakan bagian dari lembaga yang menjunjung tinggi dinamika demokrasi melalui fungsi utamanya sebagai lembaga yang menjaga kehormatan dan kewibawaan UUD.

\section{Pembentukan Peradilan Khusus Pemilu}

Berdasarkan rekam jejak M.K yang seringkali memberikan keputusan fenomenal dan memuaskan hati pencari keadilan, maka rakyat menjadi semakin yakin jika perselisihan pemilu dan pemilukada yang semula menjadi ranah wilayah Mahkamah Agung untuk sengketa hasil pemilukada masuk menjadi ranah kewenangan Mahkamah Konstitusi maka keadilan yang selama ini diinginkan akan terwujud. Harapan-harapan besar dari rakyat Indonesia ini akhirnya menjadikan Mahkamah Konstitusi tidak hanya bertugas sebagai pengawal konstitusi ("the guardian of constitution") melainkan juga sebagai pengawal demokrasi ("the guardian of democracy").

Sebagai pengawal demokrasi khususnya dalam memutus sengketa pemilu, Mahkamah Konstitusi hanya berwenang memutus perselisihan hasil pemilu (PHPU) bukan pada ranah administrasi apalagi pidananya. Dan keputusan Mahkamah Konstitusi perihal PHPU adalah final dan mengikat. Hal ini berdampak pada banyaknya permohonan gugatan sengketa hasil pemilu setiap selesai pelaksanaan pemungutan suara.

Jika kita mengacu pada praktik Mahkamah Konstitusi diberbagai belahan 
negara di dunia, tidak semua Mahkamah Konstitusi diberikan wewenang untuk memutus sengketa hasil pemilu. Ada beberapa negara yang Mahkamah Konsitusinya tidak mempunyai kewenangan menyelesaikan sengketa hasil pemilu seperti Rusia, Chechnya, Italia, Slovenia ${ }^{24}$.

Berbeda halnya dengan di Indonesia, untuk menyelesaikan berbagai masalah hukum pemilu mengalami berbagai dinamikanya. Pada Pemilu 1955 kerangka hukumnya disusun sangat sederhana sehingga berdasarkan UU No.7 Tahun 1953 hanya mengenal satu masalah hukum pemilu yaitu tindak pidana pemilu ${ }^{25}$. Dengan tujuan dan maksud yang berbeda, UU No.15 Tahun 1969 (dengan empat kali perubahan) juga hanya mengenal satu masalah hukum pemilu, yakni tindak pidana pemilu ${ }^{26}$.

Pasca runtuhnya orde baru, pemilu dipercepat dengan mendasarkan pada UU No.3 tahun 1999 yang menyebutkan ada empat masalah hukum pemilu yakni pelanggaran pidana pemilu, pelanggaran administrasi pemilu, pelanggaran tata cara pemilu dan sengketa pemilu ${ }^{27}$.

Dalam perjalanannya, UU No.3 Tahun 1999 mengalami perbaikan dengan UU No.12 Tahun 2003 dan UU No.23 Tahun 2003 dengan mempertegas masalah hukum pemilu yakni pelanggaran pidana pemilu, pelanggaran administrasi pemilu, sengketa dalam penyelenggaraan pemilu dan perselisihan hasil pemilu ${ }^{28}$.

\footnotetext{
${ }^{24}$ Baca dalam Soimin dan Mashuriyanto, Mahkamah Konstitusi Dalam Sistem Ketatanegaraan Indonesia,(Yogyakarta:UII Press,2013), h, .93-109

25 Diatur dalam Pasal 113-129 UU No.7 Tahun 1953

26 Diatur dalam Pasal 26-29 UU No.15 Tahun 1969

27 Diatur dalam Pasal 72-75 untuk ketentuan pidana, Sedangkan untuk pelanggaran administrasi dan tata cara pemilu diatur dalam PP No.33 Tahun 1999 . Untuk sengketa pemilu diatur dalam pasal 26 UU No.3 Tahun 1999

28 Untuk ketentuan pidana diatur dalam
}

Untuk lembaga-lembaga tempat memproses pelanggaran pemilu tersebut maka untuk pelanggaran tindak pidana pemilu di pengadilan umum dari $\mathrm{PN}$ hingga MA, untuk pelanggaran administrasi ditempatkan pada PTUN dan perselisihan hasil pemilu di M.K ditambah 1 (satu) lembaga penegak kode etik penyelenggara pemilu yaitu DKPP. Maka tidak heran jika kemudian beberapa ahli dan pengamat mengatakan bahwa pemilu di Indonesia adalah pemilu yang berbiaya tinggi, tidak efektif dan efesien karena melibatkan banyak lembaga penyelenggara pemilu dan lembaga peradilan ${ }^{29}$. Selain itu juga berbeda bedanya lembaga peradilan yang menyelesaikan sengketa pemilu menimbulkan ketidaktepatan waktu dalam penyelesaian sengketanya. Khususnya jika masuk ranah peradilan Tata Usaha Negara.

Karena putusan pengadilan Tata Usaha Negara tidak menjadi alasan untuk menunda tahapan pemilukada, KPUD cenderung meneruskan tahapan pemilukada. Bahkan, kalaupun calon yag tersisih tadi menang di PTUN, KPUD bisa tetap meneruskan tahapan tanpa menyertakan pasangan calon tersebut, dengan mengajukan banding ke Pengadilan Tinggi TUN. Akibatnya, calon yang dicoret tidak akan bisa mengikuti pemungutan suara ${ }^{30}$.

Dalam perjalananannya, karena banyaknya kasus berkaitan dengan peradilan umum di Mahkamah Agung

Pasal 137-141 UU No.12/2003 dan Pasal 88-92 UU No.23/2003. Untuk pelanggaran administrasi diatur dalam Pasal 130 UU No.12/2003 dan pasal 82 UU No.23/2003.Tentang sengketa dalam penyelenggaraan pemilu diatur dalam Pasal 122-129 serta pasal 77-81 UU No.12/2003 dan mengenai perselisihan hasil diatur dalam pasal 134 UU No.12/2003 dan Pasal 85 UU No.23/2003.

29 Bandingkan dalam Pramono Anung Wibowo, Mahalnya Demokrasi Memudarnya Ideologi,(Jakarta:Kompas, 2013)

30 Saldi Isra, Pemilu dan Pemulihan Daulat rakyat, (Jakarta:Themis Publishing, 2017), h,79 
yang tidak terselesaikan dan menurunnya tingkat kepercayaan masyarakat kepada Mahkamah Agung, maka berdasarkan Pasal 236C UU No.12 Tahun 2008 secara tegas telah mengalihkan kewenangan Mahkamah Agung dalam penyelesaian sengketa pemilukada kepada Mahkamah Konstitusi.

Namun uniknya dalam perjalanannya melalui putusan M.K No.97/PUU-XI/2013 kembali M.K menolak menyelesaikan sengketa hasil pemilukada karena menganggap pemilukada bukan rezim pemilu sebagaimana diatur dalam Pasal 22E ayat (2) UUD 1945. Oleh pembuat Undang-Undang keputusan M.K ini disiasati dengan munculnya pasal 157 UU Nomor 10 Tahun 2016 tentang perubahan Kedua atas Undang-Undang No.1 Tahun 2015 tentang Penetapan Peraturan Pemerintah Pengganti Undang-Undang No.1 Tahun 2014 tentang Pemilihan Gubernur, Bupati dan Walikota menjadi Undang-Undang bahwa selama belum adanya peradilan khusus, maka sengketa hasil pemilukada diperiksa dan diadili oleh Mahkamah Konstitusi.

Dalam kenyataannya, dengan melihat volume jumlah perkara yang ada, Mahkamah Konstitusi cenderung akhirnya menjadi Mahkamah Sengketa Pemilu (Election Court) karena jumlah perkara sengketa pemilu yang ditangani lebih banyak volumenya dibandingkan pengujian undang-undang (Judicial Review) yang merupakan kewenangan utama sebuah Mahkamah Konstitusi. Kewenangan baru ini ternyata juga mengubah irama kehidupan dan suasana kerja di MK. Para hakim konstitusi maupun pegawai MK pada bulan tertentu harus bekerja ekstra keras dan dalam durasi waktu yang panjang untuk menyelesaikan sengketa pemilukada yang masuk ke $\mathrm{MK}^{31}$.

31 Uraian lebih lanjut dapat dibaca dalam studi efektifitas penyelesaian sengketa hasil pemilukada oleh Mahkamah Konstitusi, Pusat
Pada sisi lain, perluasan terhadap kewenangan MK dalam menyelesaikan sengketa hasil Pemilukada ini disebabkan karena tidak tegasnya pengaturan yang dibuat pemerintah khususnya dalam hal terjadinya beragam pelanggaran yang terjadi dalam pelaksanaan Pemilukada, sehingga hal ini berdampak pada kualitas pelaksanaan Pemilukada yang tercermin pada setiap pelaksanaannya. Pengaturan terhadap pelanggaran yang ringan ini memunculkan peluang adanya kecurangan yang terstruktur dan sistematis yang mengabaikan prinsip murni dari tegaknya prinsip kedaulatan masyarakat dalam melaksanakan konstitusionalitas politiknya pada saat Pemilukada berlangsung.

Hamdan Zoelva, menyatakan bahwa terjadinya pelanggaran pelanggaran dalam pelaksanaan Pemilukada antara lain disebabkan karena regulasi Pemilukada yang memiliki banyak kekurangan, antara lain terlalu ringannya sanksi atas pelanggaran aturan Pemilukada serta minimnya pengaturan mengenai pembatasan dan transparansi keuangan dana Pemilukada ${ }^{32}$.

Lebih lanjut dikatakan bahwa sesungguhnya nilai fiilosofi terhadap pengaturan sanksi dari sebuah undang-undang pemilu termasuk undang-undang yang menjadi payung hukum Pemilukada adalah didasarkan pada anggapan bahwa pemilu adalah pesta demokrasi. Oleh karena itu, sebagai suatu pesta, diperkirakan akan banyak sekali pelanggaran, sehingga sanksi tidak diperberat. Demikian juga, mengenai pembatasan dan transparansi keuangan dana kampanye, termasuk sanksi atas pelanggaran tersebut, tidak diatur secara

Penelitian dan Pengkajian Perkara, Pengelolaan teknologi Informasi dan Komunikasi Kepaniteraan dan Sekretariat Jenderal Mahkamah Konstitusi Republik Indonesia, 2012, h, 3

32 Hamdan Zoelva, Problematika Penyelesaian Sengketa Hasil Pemilukada oleh Mahkamah Konstitusi, dalam Jurnal Mahkamah Konstitusi, Volume 10, Nomor 3, September 2013, h, 384 . 
ketat dan dengan sanksi yang ringan karena partai-partai politik yang menyusun undang-undang ini, tidak menghendaki adanya pengaturan yang mempersulit partai-partai politik dan peserta Pemilukada ${ }^{33}$.

Kasus di Indonesia hampir sama dengan yang terjadi di negara-negara lain didunia seperti Uruguay, Brazil dan Kostarica. Dimana di negara-negara tersebut, tugas Mahkamah Konstitusi juga menyelesaikan sengketa hasil pemilihan umum (Pemilu).

Maka amandemen Pasal 18 ayat (4), 22E ayat (2) ,24C ayat (1) UUD 1945 menjadi sebuah keharusan demi memperbaiki kinerja lembaga peradilan di Indonesia. Salah satu poin krusial dalam amandemen pasal-pasal tersebut adalah menerjemahkan arti pemilu dan pemilukada. Karena hal ini akan berpengaruh pada pembentukan badan khusus peradilan pemilu atau Mahkamah Pemilu dan kewenangannya. Mahkamah Agung tetap dalam posisinya menyelesaikan sengketa peradilan umum, Mahkamah Konstitusi dikurangi kewenangannya tidak lagi memutus hasil pemilu.

Hal ini tidak terlepas dari adanya tiga isu fundamental dalam penyelesaian sengketa pemilu, yaitu (1) validitas hasil, dan dengan demikian hak untuk menguji atau menggugat hasil pemilu;(2) tindakan administratif dari penyelenggara pemilu untuk memperbaiki atau menyelesaikan suatu masalah, yang dipersoalkan oleh para pencari keadilan yang hak-hak pemilu dilanggar;dan(3) tuntutan pidana bagi mereka yang melakukan tindak pidana pada proses pemilu ${ }^{34}$.

Pengaturan hukum yang komprehensif, jelas dan tepat tentu dengan sendirinya akan menghasilkan pelaksanaan Pemilu dan Pemilukada yang

33 Ibid

34 Ramlan Surbakti dalam Zainal Arifin Hoesein dan Rahman Yasin, Pemilihan Kepala Daerah Langsung (Penguatan Konsep dan Penerapannya), (Jakarta: LP2AB, 2015), h, 155 berkualitas dan jauh dari beragam potensi pelanggaran dalam segala bentuknya. Pengaturan ini pada akhirnya akan "menghilangkan" perluasan kewenangan MK dalam hal memutus sengketa hasil Pemilukada yang secara konseptual praktis terjebak pada konteks matematik penghitungan suara melanggar atau tidak dalam pelaksanaannya. Satu sisi dengan perluasan kewenangan ini memberikan pintu harapan masyarakat dalam menjaga konstitusionalitas berdemokrasinya, tapi pada sisi lain akan menghindarkan MK dari bayang-bayang kepentingan politik yang setiap saat akan mengintai dan mengganggu eksistensi sekaligus kredibilitas lembaga yang secara konstitusi keberadaannya sangat dihormati.

Sehingga persoalan-persoalan administrasi dalam penyelengaraan Pemilu dan Pemilukada baik yang berkaitan dengan proses-proses awal hingga akhir pada saat penghitungan suara, jika hal itu ditemukan suatu pelanggaran hukum, maka seyogyanya dikembalikan pada Peradilan diluar MK, yaitu dapat diselesaikan oleh Mahkamah Pemilu. Mahkamah Pemilu ini tentu harus dipertimbangkan keberadaanya. Penulis berpandangan bahwa Mahkamah Pemilu ini dapat diwujudkan dalam dua hal. Pertama, dengan mengoptimalkan peran dari lembaga DKPP yang selama ini hanya berkutat pada persoalan-persolan etik penyelenggara Pemilukada, dan Kedua, Mahkamah Pemilu ini dapat berupa Peradilan Ad Hoc yang dibentuk oleh Mahkamah Agung, yang keberadaannya disiapkan pada saat adanya pesta demokrasi atau Pemilukada. Hakim Ad Hoc ini tentu tidak hanya terdiri dari Hakim MA melainkan dapat juga melibatkan kalangan profesional yang memiliki kapasitas dan kompetensi keilmuan secara hukum khususnya Hukum Pemilu.

Dengan bermaksud untuk lebih membuat efisiensi dan efektifitas kelembagaan peradilan, maka keberadaan 
Mahkamah Pemilu ini merupakan pengejahwantahan atau beralih fungsinya lembaga yang sudah ada yaitu dengan cara memperluas kewenangan DKPP. DKPP tidak hanya menyelesaikan dan menjaga kehormatan etika penyelenggara pemilu saja namun juga diberi beban untuk menyelesaikan seluruh sengketa dan pelanggaran pemilu. Realita ini mempunyai konsekuensi berubahnya nama DKPP menjadi Mahkamah Pemilu dan penguatan kelembagaanya.

Dari kedua alternatif ini menurut hemat penulis yang paling memungkin adalah penguatan terhadap lembaga DKPP, sehingga keberadaam lembaga ini tidak hanya fokus pada persoalan etik penyelenggara Pemilukada, tetapi juga dapat menjaga kemurnian konstitusionalitas berdemokrasi dari setiap warga negara dan tentu saja akan berdampak pada pemurnian lembaga MK dari kepentingan politik pada pelaksanaan Pemilu dan Pemilukada. Hal ini didasarkan pada kasus-kasus yang melibatkan Hakim MK pada masa lalu yang terjerat pada persoalan-persoalan hukum, baik etik maupun yang telah terbawa arus persoalan tindak pidana korupsi dan telah ditangani oleh KPK.

Dalam konsep proses transisi demokrasi di Indonesia, maka Mahkamah Pemilu atau sebutan lain akan memiliki peran dan fungsi untuk mengawal tegaknya kedaulatan rakyat sebagaimana dijamin dalam UUD 1945. Sehingga akan meringankan beban Mahkamah Konstitusi yang tentunya akan lebih fokus untuk mengawal dan menjaga konstitusi sebagai hukum tertinggi (the supreme law of the land). Terpenting, dengan kehadiran Mahkamah Pemilu melalui penguatan terhadap DKPP akan melahirkan sekaligus menjaga para Hakim MK agar tidak terjebak pada persoalan-persoalan politik kepentingan dari pemilu dan Pemilukada itu sendiri. Hal ini tentu akan mengembalikan fungsi MK sebagai sebuah peradilan konstitusi yang mengemban fungsi utama "the guardian of the Constitution" yang dilakukan melalui judicial review.

\section{P E N U T U P}

Berdasarkan pada analisis uraian sebagaimana dimaksud diatas, penulis dapat menyimpulkan bahwa penyelesaian sengketa hasil Pemilu dan Pemilukada oleh MK kedepan perlu sebuah terobosan hukum yang fundamental, yakni dengan mengembalikan dan memurnikan keberadaan MK sebagai lembaga Peradilan Konstitusi yang memiliki fungsi utama srebagai "the guardian of the Constitution" melalui mekanisme judicial review, dimana hal ini akan mengembalikan kredibiltas lembaga dan personal Hakim MK dari jerat kepentingan politik kekuasaan yang setiap saat mengancam marwah dan kehormatan MK sebagai Peradilan Konstitusi. Untuk itu, penguatan terhadap lembaga DKPP merupakan sebuah keniscayaan disaat Hakim MK terjebak pada kepentingan politik kekuasaan Pemilu dan Pemilukada. Pada sisi lain penyelamatan terhadap kemurnian lembaga MK juga dapat ditempuh dengan pembentukan Hakim Ad Hoc oleh MA yang keberadaannya dapat dibentuk pada saat pelaksanaan Pemilu dan Pemilukada.

Disamping itu, Mahkamah Konstitusi adalah bagian dari kekuasaan kehakiman di luar Mahkamah Agung, yang secara yuridis kewenangan Mahkamah Konstitusi dimaksudkan untuk memeriksa, mengadili dan memutus sengketa atau perselisihan tentang hasil Pemilu dan Pemilukada sebagimana tertuang dalam ketentuan Pasal 24C ayat (1) UUD NRI 1945. Oleh karena itu, Mahkamah Konstitusi disamping berfungsi sebagai pengawal konstitusi, penafsir konstitusi, juga adalah pengawal demokrasi (the guardian and the sole interpreter of the constitution, as well as the guardian of the process of democratization).

Pemahaman terhadap pengawal 
demokrasi ini, haruslah dapat ditafsirkan atau dipahami tidak semata-mata dalam konteks Pemilu dan Pemilukada. Dalam konteks ketatanegaraan khususnya dalam kehidupan berbangsa dan bernegara, penerapan sistem demokrasi tidak hanya berkaitan dengan pelaksanaan Pemilu dan Pemilukada, namun lebih dari sekedar itu, demokrasi harus dipahami sebagai sebuah sistem pemerintahan yang luas dan selalu memberikan peluang-peluang bagi setiap warga negara Indonesia untuk mengekspresiasikan diri baik dalam aspek politik, hukum, ekonomi maupun aspek lainnya sepanjang hal itu menyangkut hak-hak konstitusional dan kewajiban konstitusional sebagai warga negara. Pemahan inilah kiranya yang harus diluruskan dan ditegakkan. Artinya, walaupun kedepan kewenangan MK terkait perselisihan sengketa hasil Pemilu dan Pemilukada "ditiadakan", bukan berarti MK sebagai lembaga Pengawal Demokrasi pada hakikaktnya tidak akan sirna, karena sesungguhnya MK sebagai lembaga Pengawal Konstitusi pada hakikatnya mengandung dan mencerminkan sebagai lembaga yang setiap saat hadir untuk menjaga dan melindungi Konstitusi yang secara nyata didalamnya menuangkan seluruh aspek kehidupan berbangsa dan bernegara

\section{DAFTAR PUSTAKA}

Abdurrahman Satrio, 2015. Kewenangan Mahkamah Konstitusi Memutus Perselisihan Hasil Pemilu Sebagai Bentuk Judicialization of Politics, Jurnal Konstitusi,Volume 12 Nomor 1 Maret ,Jakarta:Mahkamah konstitusi

Benny K. Harman, 2013. Mempertimbangkan Mahkamah Konstitusi, Jakarta:Gramedia.

Feri Amsari, 2013. Perubahan UUD 1945,Jakarta:Rajawali Press.

Hamdan Zoelva, 2013. Problematika Penyelesaian Sengketa Hasil
Pemilukada oleh Mahkamah Konstitusi, dalam Jurnal Mahkamah Konstitusi, Volume 10, Nomor 3, September,Jakarta:Mahkamah Konstitusi

Jimly Asshidiqie, 2005. Model-Model Pengujian Konstitusional di Berbagai Negara, Jakarta:KONpress.

Mukhlis Taib, 2017. Dinamika Perundang-Undnagan di Indonesia, Jakarta: Reflika Aditama.

Ni'matul Huda dan R.Nazriyah, 2011. Teori dan Pengujian Peraturan Perundang-Undangan, Bandung: Nusa Media.

Pramono Anung Wibowo, 2013. Mahalnya Demokrasi Memudarnya Ideologi, Jakarta: Kompas.

Saldi Isra, 2017. Pemilu dan Pemulihan Daulat Rakyat, Jakarta: Themis Publishing

Soimin dan Mashuriyanto, 2013. Mahkamah Konstitusi Dalam Sistem Ketatanegaraan Indonesia, Yogyakarta: UII Press.

Sudirman, 2016. Memurnikan Kewenangan Mahkamah Konstitusi Sebagai Lembaga Pengawal Konstitusi, Jurnal Ilmiah Pendidikan Pancasila dan Kewarganegaraan, Tahun 1 Nomor 1 Juni 2016,Malang:Universitas Malang

Thorkis Pane, 2011. Kemungkinan Peraturan Perundang-Undangan di Bawah Undang-Undang sebagai Objek Pengujian Mahkamah Konstitusi, Jurnal Hukum dan Pembangunan, Tahun ke-41 No.3 Juli 2011, Jakarta:Universitas Indonesia.

Veri Junaidi, 2013. Mahkamah Konstitusi Bukan Mahkamah Kalkulator, Jakarta: Themis Book

Widodo Ekatjahjana, 2007. Pengujian Peraturan Perundang-Undangan Menurut UUD 1945, Sebuah 
disertasi Progam Pasca Sarjana UNPAD, Tahun 2007

Zainal,Arifin Hoesein dan Rahman Yasin, 2015. Pemilihan Kepala Daerah Langsung (Penguatan Konsep dan Penerapannya), Jakarta: LP2AB.

\section{Internet}

http://www.hukumonline.com/berita/baca /lt4d54dda21b2c0/hakim-arsyad-ter bukti-langgar-kode-etik,

http://orintononline.blogspot.co.id/2013/0 2/teori-hukum-murni.html,

http://www.Kbbi.kata.web.id/memurnika $\mathrm{n} /$

http://nasional.kompas.com/read/2017/09 /12/10124921/patrialis-akbar-tidakajukan-banding-atas-vonis-8-tahunpenjara

\section{Undang-Undang}

UUD 1945

Undang-Undang No.7 Tahun 1953

Undang-Undang No.3 Tahun 1999

Undang-Undang No.12 Tahun 2003

Undang-Undang No.23 Tahun 2003

Undang-Undang No.32 Tahun 2004
Undang-Undang No.12 Tahun 2008 tentang Pemerintahan Daerah

Undang-Undang No.1 Tahun 2015 tentang Penetapan Peraturan Pemerintah Pengganti Undang-Undang No.1 Tahun 2014 tentang Pemilihan Gubernur, Bupati dan Walikota menjadi Undang-Undang

Undang-Undang No.10 Tahun 2016 tentang Pemilihan Gubernur, Bupati dan Walikota 